\title{
Article \\ ITS DNA Barcoding Reveals That Halophila stipulacea Still Remains the Only Non-Indigenous Seagrass of the Mediterranean Sea
}

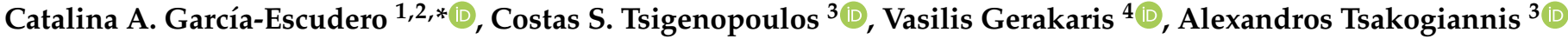 \\ and Eugenia T. Apostolaki ${ }^{1}$ (I)
}

1 Institute of Oceanography, Hellenic Centre for Marine Research, P.O. Box 2214, GR-71003 Heraklion, Crete, Greece; eapost@hcmr.gr

2 Biology Department, Voutes University Campus, University of Crete, P.O. Box 2208, GR-70013 Heraklion, Crete, Greece

3 Institute of Marine Biology, Biotechnology and Aquaculture, Hellenic Centre for Marine Research, P.O. Box 2214, GR-71003 Heraklion, Crete, Greece; tsigeno@hcmr.gr (C.S.T.); tsakalex@hcmr.gr (A.T.)

4 Institute of Oceanography, Hellenic Centre for Marine Research, P.O. Box 712, GR-19013 Anavyssos, Attiki, Greece; vgerakaris@hcmr.gr

* Correspondence: cagarcia3@uc.cl; Tel.: +30-698-587-4976

check for updates

Citation: García-Escudero, C.A.; Tsigenopoulos, C.S.; Gerakaris, V.; Tsakogiannis, A.; Apostolaki, E.T. ITS DNA Barcoding Reveals That Halophila stipulacea Still Remains the Only Non-Indigenous Seagrass of the Mediterranean Sea. Diversity 2022, 14 76. https://doi.org/10.3390/ d14020076

Academic Editor: Bert W. Hoeksema

Received: 22 December 2021

Accepted: 17 January 2022

Published: 22 January 2022

Publisher's Note: MDPI stays neutral with regard to jurisdictional claims in published maps and institutional affiliations.

Copyright: (C) 2022 by the authors. Licensee MDPI, Basel, Switzerland. This article is an open access article distributed under the terms and conditions of the Creative Commons Attribution (CC BY) license (https:// creativecommons.org/licenses/by/ $4.0 /)$.

\begin{abstract}
Non-indigenous species (NIS) are one of the major threats to the native marine ecosystems of the Mediterranean Sea. Halophila stipulacea was the only exotic seagrass of the Mediterranean until 2018, when small patches of a species morphologically identified as Halophila decipiens were reported in Salamina Island, Greece. Given the absence of reproductive structures during the identification and the taxonomic ambiguities known to lead to misidentifications on this genus, we reassessed the identity of this new exotic record using DNA barcoding (rbcL, matK and ITS) and the recently published taxonomic key. Despite their morphologic similarity to H. decipiens based on the new taxonomic key, the specimens showed no nucleotide differences with $\mathrm{H}$. stipulacea specimens (Crete) for the three barcodes and clustered together on the ITS phylogenetic tree. Considering the high species resolution of the ITS region and the common morphological variability within the genus, the unequivocal genetic result suggests that the Halophila population found in Salamina Island most likely corresponds to a morphologically variant $H$. stipulacea. Our results highlight the importance of applying an integrated taxonomic approach (morphological and molecular) to taxonomically complex genera such as Halophila, in order to avoid overlooking or misreporting species range shifts, which is essential for monitoring NIS introductions.
\end{abstract}

Keywords: biological invasions; species range shifts; species monitoring; integrative taxonomy; seagrass barcoding; Halophila decipiens; morphologic variability; phenotypic plasticity; species misidentification

\section{Introduction}

The natural ranges of species are inherently dynamic, but in recent decades globalization and climate change have accelerated the pace of change by facilitating the introduction of species outside their natural ranges [1-3]. Non-indigenous species (NIS) that become established and spread can pose a major threat to native biodiversity and community structure, affecting the integrity and function of natural ecosystems [4,5]. This is particularly evident in the Mediterranean Sea, which is currently considered the most invaded marine basin globally [6,7], with nearly 700 multicellular established NIS documented up to March $2021[8,9]$. The vast majority occur in the eastern subregion and probably entered the basin through the Suez Canal, which since 1869 connects the Mediterranean Sea with the IndoPacific region [10-12]. This artificial passage, combined with the high volume of shipping routes, aquaculture, aquarium trade [12,13], and recent warming of Mediterranean waters due to climate change, makes the basin vulnerable to the introduction of NIS [14,15]. This 
is especially true for the eastern subregion, which is warming faster than the rest of the basin [16], leading to an assemblage restructuring shaped by the native species in peril and a replacement by tropical ones [17-19].

In the Mediterranean Sea, seagrass communities dominate the sublittoral environment and provide several important ecosystem services $[20,21]$. Of the seagrass species that occur in this basin, Halophila stipulacea (Forsskål) Ascherson, 1867 is the smallest species known to be among the first Lessepsian migrants [22-24]. Originally native to the western part of the Indian Ocean, including the Red Sea, the Arabian Sea, and the Persian Gulf [25], this species was first reported in Rhodes, Greece, in 1894 [26]. Since then, it has progressively spread throughout the Mediterranean, colonizing the eastern and central subregions and, in recent decades, the western subregion [27], including populations off the coasts of Italy [9,28,29], Tunisia [30,31], and, more recently, Cannes on the French Riviera [32]. So far, the Mediterranean invasion can be described as slow and punctuated in space [27]. It generally colonizes habitats devoid of native macrophytes or occasionally forms mixed meadows with the native Cymodocea nodosa (Ucria) Ascherson, 1870, which is opposite to its invasion of the eastern Caribbean islands, where it spreads rapidly and displaces several native macrophytes $[27,33]$. However, its invasion dynamics are expected to change as the basin becomes saltier and warmer, favoring the establishment of tropical and subtropical species [14,34], and, as the endemic meadows of Posidonia oceanica (L.) Delile, 1813 continue to decline $[35,36]$ leaving new suitable habitats available for fast-growing opportunistic macrophytes to recolonize. Invaders tend to be stronger colonizers than native species, so the recolonization of declining meadows could likely be dominated by invasive macrophytes such as H. stipulacea, Caulerpa taxifolia, and Caulerpa racemosa over the natives C. nodosa and Caulerpa prolifera $[37,38]$. Changes in the seagrass biogeography, including the replacement of native P. oceanica by species with a lower habitat complexity and the shift from seagrass meadows to algae, could inevitably lead to dramatic changes in the dynamics and function of coastal ecosystems [31,34].

Halophila stipulacea was considered the only non-indigenous seagrass species in the Mediterranean until October 2018, when several small patches $\left(1\right.$ to $\left.10 \mathrm{~m}^{2}\right)$ of a species identified as H. decipiens were found in Salamina Island in the Saronikos Gulf, Greece [39]. $H$. decipiens is a pantropical species with a wide geographic distribution, originally occurring in tropical, subtropical, and warm-temperate systems in both hemispheres [40,41]. Similar to H. stipulacea, it is a fast-growing species with a high phenotypic plasticity and the ability to live in a wide range of temperatures, salinities, light irradiances, and substrates [42-44] -all typical characteristics of invasive species. The introduction of another exotic seagrass would pose a new, unpredictable threat to native coastal ecosystems. Close monitoring would be required as it is difficult to predict at an early stage whether a new introduction would be an ephemeral event or whether it would become established and spread throughout the basin. Containment, eradication, and management plans become more difficult or even impossible when an NIS becomes abundant and widespread [45,46]. Therefore, the ability to rapidly and accurately identify and monitor NIS introductions plays an essential role in mitigating the threats posed by them [47].

Traditional morphology-based species identification works as a standard method for many taxa. However, early life stages of species, ambiguous or uninformative morphological characters, high phenotypic plasticity, morphologically cryptic species, and a lack of taxonomic expertise can compromise the accuracy of this method, leading to misidentifications or uncertainties that can obscure invasion histories and preclude appropriate management strategies [48]. In the face of these and other difficulties, traditional taxonomy has evolved into an integrative approach in which species are studied from multiple complementary perspectives, including morphological, molecular, behavioral, developmental, and ecological characterizations [49]. Most molecular studies have focused on animals, given the remarkable success of the mitochondrial cytochrome oxidase c subunit 1 (COI) gene as a universal single DNA barcode for metazoans [50,51]. In contrast, plants' much slower substitution rate of the COI and other mitochondrial genes does not generate a suffi- 
cient intergenetic distance to discriminate between species in most plant groups [52]. This has led to an extensive and difficult search for an alternative region in the mitochondrial, plastid, and nuclear genome [52-54]. Multiple candidates have been proposed, however, no consensus has been reached on a single universal plant DNA barcode, limiting the application of this technique to these organisms [55]. Currently, although they are taxa-specific and achieve different degree of success, the plastid rbcL (ribulose-bisphosphate carboxylase) and matK (maturase K) and the nuclear trnH-psbA and ITS (internal transcribed spacer) regions, are widely used and considered effective markers for species identification and phylogenetic reconstruction for land plants and seagrasses [56-61].

The taxonomic classification of the genus Halophila is a major challenge, and changes in species delimitation and misidentifications occur frequently [62]. The difficulty lies in the high fragility and small size of the species, the simplicity and frequent absence of reproductive structures (e.g., petals, sepals, stamens, fruits, and seeds), and the limited number of vegetative characters (e.g., the plant's appearance, leaf length and width, leaf margin and tips, number of cross-veins, and branching), which occasionally show considerable variation and overlap with species living in similar environments $[25,63]$. Molecular analyses have already helped to clarify some species delimitations and resolve previous morphological misidentifications $[57,64,65]$, supporting the idea that an integrative taxonomic approach is necessary for a taxonomically complex genus such as Halophila. In the case of the recent first record of $H$. decipiens in the Mediterranean, its taxonomic identification was based only on vegetative morphological characters, as the reproductive structures found were still at an early stage. Considering the importance of species-level accuracy for reporting and monitoring NIS introductions and the problematic taxonomy of the genus Halophila, the aim of this study was to reassess the species identification of the first record of $H$. decipiens in the Mediterranean Sea using DNA barcoding. By doing so, we support the idea that DNA barcoding can be employed as a rapid and accurate complementary tool for seagrass species identification and assist with monitoring range shifts in taxonomically complex and potentially invasive genera such as Halophila.

\section{Materials and Methods}

\subsection{Morphological Identification}

The specimens of Halophila decipiens found in Salamina Island [39] were identified following the descriptions of Phillips and Mehez (1988) [66] and the taxonomic key of Kuo and den Hartog (2001) [63]. Since then, a new taxonomic key for the Halophila genus was published by Kuo (2020) [62]. Here we used the compiled information of the latter key with the older keys to re-identify the collected specimens. Generative characters were not available (i.e., reproductive structures were not fully developed), so identification of Halophila species was based only on vegetative morphological characters. Reference images of $H$. stipulacea specimens were included for visual comparison.

\subsection{Sample Collection}

For the DNA barcode identification, samples of the specimens morphologically described as H. decipiens, named Halophila sp. for this study, were collected in November 2019 from the exact location where the first population was reported. A patchy meadow located on a shallow (3-4 m deep) sandy area on the south coast of Salamina Island, Saronikos Gulf, Aegean Sea, Greece ( $37^{\circ} 52^{\prime} 44.4^{\prime \prime}$ N, $23^{\circ} 27^{\prime} 39.6^{\prime \prime}$ E). For comparison, samples of H. stipulacea were collected in May 2019 from a 20 m depth meadow near Hersonissos, Crete, Greece $\left(35^{\circ} 18^{\prime} 53.74^{\prime \prime} \mathrm{N}, 25^{\circ} 25^{\prime} 7.23^{\prime \prime} \mathrm{E}\right)$. The populations correspond to monospecific seagrass meadows. On both samplings, four individual plant modules (each module consisted of a section of rhizome, a node, and one mature leaf pair) were randomly collected by hand at 1-2 $\mathrm{m}$ from each other using scuba-diving. The entire plant modules were submerged in RNAlater ${ }^{\mathrm{TM}}$ Stabilization Solution and stored at $20{ }^{\circ} \mathrm{C}$ for future molecular analysis. 


\subsection{DNA Isolation, PCR Amplification, and Sequencing}

The plant material (leaf tissue) of each sample was homogenized using a mortar and pestle under a constant addition of liquid nitrogen. From the finely powdered leaf produced, 100-150 mg was used for the DNA isolation following a modified cetyltrimethylammonium bromide (CTAB) chloroform/isoamyl alcohol (24:1) isolation protocol including an RNase treatment (RiboShredder RNase Blend, Epicentre, Madison, WI, USA) of $1 \mathrm{~h}$ at $37^{\circ} \mathrm{C}$. The final DNA pellet was resuspended in $50 \mu \mathrm{L}$ of Buffer AE (QIAGEN, Hilden, Germany). The DNA quality was checked on a $1 \%$ agarose gel stained with ethidium bromide. The concentration and purity were quantified using a NanoDrop ND 1000 (NanoDrop Technologies, Wilmington, DE, USA). Based on the Consortium for the Barcoding of Life (CBOL) plant barcoding recommendations [58] and previous seagrass DNA barcoding studies $[56,57,60,61]$, the ITS1-5.8S-ITS2 (ITS), rbcL and matK regions were selected for the study. The primers P609 (5'-GTAAAATCAAGTCCACCRCG-3') and P610 (5'-ATGTCACCACAAACAGAGACTAAAGC-3') were used to amplify sequences of $\sim 600 \mathrm{bp}$ corresponding to rbcL. Primers P646 (5'-TAATTTACGATCAATTCATTC-3') and P647 (5'-GTTCTAGCACAAGAAAGTCG-3') were used to amplify sequences of $\sim 945 \mathrm{bp}$ corresponding to matK. Last, primers P674 (5'-CCTTATCATTTAGAGGAAGGAG-3') and P675 (5'-TCCTCCGCTTATTGATATGC- $3^{\prime}$ ) were used to amplify sequences of $\sim 700 \mathrm{bp}$ corresponding to the ITS region. The PCR amplifications were performed in a $15 \mu \mathrm{L}$ final reaction volume consisting of $30 \mathrm{ng}$ of template DNA, $0.45 \mu \mathrm{M}$ of forward primer, $0.45 \mu \mathrm{M}$ of reverse primer, and $7 \mu \mathrm{L}$ of DreamTaq Hot Start PCR Master Mix (Thermo Fisher Scientific, Waltham, MA, USA). PCR conditions consisted of an initial denaturation step at $95^{\circ} \mathrm{C}$ for $3 \mathrm{~min}$, followed by 30 cycles of denaturation at $95^{\circ} \mathrm{C}$ for $30 \mathrm{~s}$, annealing at $55^{\circ} \mathrm{C}$ for ITS/rbcL and at $50^{\circ} \mathrm{C}$ for matK for $35 \mathrm{~s}$, and elongation at $72^{\circ} \mathrm{C}$ for $1 \mathrm{~min}$. The 30 cycles were followed by a final extension at $72{ }^{\circ} \mathrm{C}$ for $8 \mathrm{~min}$. The PCRs were performed in a Bio-Rad T100 Thermal Cycler with a heated lid. All PCR reactions were repeated four times independently for the same individual to keep potential errors in the final consensus sequence to a minimum. A manual ethanol/sodium acetate precipitation protocol was used to purify the PCR products. DNA sequencing reactions were performed using the Applied Biosystems ${ }^{\mathrm{TM}}$ BigDye $^{\mathrm{TM}}$ Terminator (Thermo Fisher Scientific) in a $10 \mu \mathrm{L}$ total volume and run on an ABI 3730 automated DNA sequencer.

\subsection{Data Analysis}

Consensus sequences were assembled by combining the forward and reverse sequences previously end-trimmed based on average quality scores, using CodonCode Aligner v9.0.1.3 (CodonCode Co., Centerville, MA, USA). The sequences were aligned using the CLUSTAL W [67] algorithm in MEGA 7 [68], and the alignments were checked and adjusted by eye to exclude obvious alignment errors. For the phylogenetic analysis, known ITS sequences of H. decipiens, H. stipulacea, and other Halophila species were retrieved from GenBank (https: / / www.ncbi.nlm.nih.gov/ (accessed on 13 December 2020)) and included in the alignment (Table 1). The sequences of Halophila beccari and Halophila engelmannii were used as the outgroups. The jModelTest version 2.1.6 [69] was used to find the model of nucleotide sequence evolution that best fit our data. The maximum likelihood (ML) phylogenetic tree reconstruction was performed in W-IQ-TREE [70-72] with the TIM2 + G model and visualized with the Interactive Tree Of Life (iTOL) v5 [73]. The neighbor-joining (NJ) phylogenetic tree reconstruction was performed in MEGA 7 [68] with the default Tamura-Nei $+\mathrm{d}$ model. Bootstrap values of the ML and NJ tree were estimated using 1000 replicates. The barcoding gap between $H$. decipiens and H. stipulacea was calculated based on the Automatic Barcode Gap Discovery (ABGD) method on the ABGD graphic web version using the default settings [74]. 
Table 1. GenBank accession numbers of the sequences included in the present ITS phylogenetic analysis.

\begin{tabular}{|c|c|c|c|c|c|}
\hline $\mathbf{N}^{\mathbf{o}}$ & Species & GenBank Accession & Location & Source & Ref. \\
\hline 1 & Halophila decipiens & AF395671 & Hawaii & Waycott et al., 2002 & [60] \\
\hline 2 & Halophila decipiens & AF366411 & Australia & Waycott et al., 2002 & [60] \\
\hline 3 & Halophila decipiens & AF366407 & USA & Waycott et al., 2002 & [60] \\
\hline 4 & Halophila decipiens & AF366413 & Curaçao & Waycott et al., 2002 & [60] \\
\hline 5 & Halophila decipiens & AF366409 & Costa Rica & Waycott et al., 2002 & [60] \\
\hline 6 & Halophila decipiens & AF366408 & Panama & Waycott et al., 2002 & [60] \\
\hline 7 & Halophila decipiens & AB243983 & Japan & Uchimura et al., 2008 & [57] \\
\hline 8 & Halophila decipiens & KC175913 & Vietnam & Nguyen et al., 2013 & [65] \\
\hline 9 & Halophila decipiens & MN200776 & Malaysia & Rozaimi et al., 2020 & [44] \\
\hline 10 & Halophila sp. & OM162162 & Greece & This study & - \\
\hline 11 & Halophila stipulacea & OM162166 & Greece & This study & - \\
\hline 12 & Halophila stipulacea & AF366436 & Italy & Waycott et al., 2002 & {$[60]$} \\
\hline 13 & Halophila stipulacea & AY352618 & Italy & Ruggiero et al., 2004 & [75] \\
\hline 14 & Halophila stipulacea & AY352635 & Greece & Ruggiero et al., 2004 & [75] \\
\hline 15 & Halophila stipulacea & KM609943 & Egypt & Nguyen et al., 2015 & [56] \\
\hline 16 & Halophila stipulacea & KM609944 & United Arab Emirates & Nguyen et al., 2015 & [56] \\
\hline 17 & Halophila stipulacea & KM609944 & India & Nguyen et al., 2015 & [56] \\
\hline 18 & Halophila ovalis & KF620337 & Hong Kong & Nguyen et al., 2014 & [76] \\
\hline 19 & Halophila ovalis & AF366430 & Australia & Waycott et al., 2002 & {$[60]$} \\
\hline 20 & Halophila ovalis & AF366420 & Malaysia & Waycott et al., 2002 & [60] \\
\hline 21 & Halophila ovalis & AB243975 & Japan & Uchimura et al., 2008 & [57] \\
\hline 22 & Halophila ovalis & AB436939 & Thailand & Uchimura et al., 2008 & [57] \\
\hline 23 & Halophila ovalis & AB436925 & Hawaii & Uchimura et al., 2008 & [57] \\
\hline 24 & Halophila ovalis & KF620354 & India & Nguyen et al., 2014 & [76] \\
\hline 25 & Halophila ovalis & KC175911 & Vietnam & Nguyen et al., 2013 & [65] \\
\hline 26 & Halophila hawaiiana & AF366414 & Hawaii & Waycott et al., 2002 & [60] \\
\hline 27 & Halophila johnsonii & AF366425 & USA & Waycott et al., 2002 & [60] \\
\hline 28 & Halophila major & AB436929 & Japan & Uchimura et al., 2008 & [57] \\
\hline 29 & Halophila major & AB436927 & Thailand & Uchimura et al., 2008 & [57] \\
\hline 30 & Halophila major & KC175910 & Vietnam & Nguyen et al., 2013 & [65] \\
\hline 31 & Halophila major & KF620340 & Malaysia & Nguyen et al., 2014 & [76] \\
\hline 32 & Halophila major & KF620352 & Myanmar & Nguyen et al., 2014 & [76] \\
\hline 33 & Halophila major & MT586874 & Philippines & Kolátková et al., 2021 & [77] \\
\hline 34 & Halophila major & MT028353 & Indonesia & Kolátková et al., 2021 & [77] \\
\hline 35 & Halophila minor & AF366406 & Philippines & Waycott et al., 2002 & {$[60]$} \\
\hline 36 & Halophila minor & AF366405 & Guam & Waycott et al., 2002 & [60] \\
\hline 37 & Halophila nipponica & AB36924 & USA & Uchimura et al., 2008 & [57] \\
\hline 38 & Halophila nipponica & AB523410 & Japan & Uchimura et al., 2008 & [57] \\
\hline 39 & Halophila nipponica & KX668188 & Korea & Kim et al., 2017 & [64] \\
\hline 40 & Halophila spinulosa & AF366440 & Malaysia & Waycott et al., 2002 & [60] \\
\hline 41 & Halophila spinulosa & AF366439 & Australia & Waycott et al., 2002 & [60] \\
\hline 42 & Halophila tricostata & AF366438 & Australia & Waycott et al., 2002 & [60] \\
\hline 43 & Halophila engelmannii & AF366404 & USA & Waycott et al., 2002 & [60] \\
\hline 44 & Halophila becarii & KM609945 & India & Nguyen et al., 2015 & [56] \\
\hline
\end{tabular}

\section{Results}

\subsection{Morphological Identification}

Based on the compiled information of the current taxonomic key of the genus Halophila (Kuo, 2020) [62] and the two previous keys, Phillips \& Mehez (1988) [66] and Kuo \& Den Hartog (2001) [63], the vegetative morphological characters of the specimens found in Salamina Island (Halophila sp.) match better with H. decipiens's diagnostic characters than to those of $H$. stipulacea, especially regarding the low number and type of cross-veins and the structure of the scales (Table 2 and Figure 1). 
Table 2. Vegetative characters of Halophila sp. compared to H. decipiens and H. stipulacea.

\begin{tabular}{|c|c|c|c|}
\hline \multirow[b]{2}{*}{ Character } & \multicolumn{2}{|c|}{$\begin{array}{l}\text { Phillips \& Mehez (1988) [66]; Kuo \& Den Hartog (2001 [63]); } \\
\text { Kuo (2020) [62] }\end{array}$} & \multirow{2}{*}{$\begin{array}{l}\text { This Study } \\
\text { Halophila sp. }\end{array}$} \\
\hline & Halophila decipiens & Halophila stipulacea & \\
\hline Rhizome & $\begin{array}{l}\text { Thin, fragile, fleshy, elongated, } \\
1 \mathrm{~mm} \text { diameter }\end{array}$ & $0.5-2 \mathrm{~mm}$ wide & $\begin{array}{l}\text { Thin, fleshy, smooth, elongated, } \\
<1 \text { mm diameter }\end{array}$ \\
\hline Leaf shape & $\begin{array}{l}\text { Oblong to elliptic, apex obtuse } \\
\text { or rounded, base cuneate }\end{array}$ & $\begin{array}{l}\text { Linear to oblong, elliptic, } \\
\text { cartilaginous to membranous, } \\
\text { apex obtuse, base cuneate or } \\
\text { gradually decurrent-petiolate }\end{array}$ & $\begin{array}{l}\text { Oblong to elliptic, } \\
\text { base cuneate, apex obtuse }\end{array}$ \\
\hline Leaf dimensions & $\begin{array}{l}\text { 10-25 mm long, } \\
2.5-6.5 \mathrm{~mm} \text { wide }\end{array}$ & $\begin{array}{l}\text { Up to } 60 \mathrm{~mm} \text { long, } \\
10 \mathrm{~mm} \text { wide }\end{array}$ & $\begin{array}{l}\text { 7-20 mm long, } \\
2-4 \mathrm{~mm} \text { wide }\end{array}$ \\
\hline Cross-veins & $\begin{array}{l}\text { 5-9 pairs ascending, } \\
\text { unbranched }\end{array}$ & $\begin{array}{l}10-40 \text { pairs, branched, } \\
\text { ascending at } 45-60 \text { degrees }\end{array}$ & $\begin{array}{l}\text { 6-9 pairs ascending, } \\
\text { unbranched }\end{array}$ \\
\hline Leaf margin & finely serrulate & Finely serrulate & Finely serrulate \\
\hline Leaf surfaces & $\begin{array}{c}\text { Membranous, hairy on both } \\
\text { sides or only on the ventral side, } \\
\text { sometimes glabrous }\end{array}$ & $\begin{array}{l}\text { Glabrous, or with minute hairs; } \\
\text { not papillous; occasionally bullate }\end{array}$ & $\begin{array}{l}\text { Both surfaces covered in minute } \\
\text { unicellular hairs }\end{array}$ \\
\hline Petioles & $\begin{array}{l}\text { Not sheathing, shorter than the } \\
\text { blades, 3-15 mm long }\end{array}$ & $\begin{array}{l}\text { Sheathing lopsidedly at the base, } \\
\text { shorter than the blades, } \\
5-15 \mathrm{~mm} \text { long }\end{array}$ & $\begin{array}{l}\text { Shorter than the blades, } \\
1-26 \mathrm{~mm} \text { long }\end{array}$ \\
\hline Scales & $\begin{array}{l}\text { Transparent, usually } \\
\text { hairy outside }\end{array}$ & $\begin{array}{l}\text { Large, elliptic, or obovate } \\
\text { transparent scales; } 12-17 \mathrm{~mm} \\
\text { long; } 6-10 \mathrm{~mm} \text { wide; folded at the } \\
\text { rhizome nodes covering } \\
\text { (sheathing) petioles }\end{array}$ & $\begin{array}{c}\text { Short, obovate, transparent, not } \\
\text { sheathing the } \\
\text { petioles lopsidedly }\end{array}$ \\
\hline
\end{tabular}
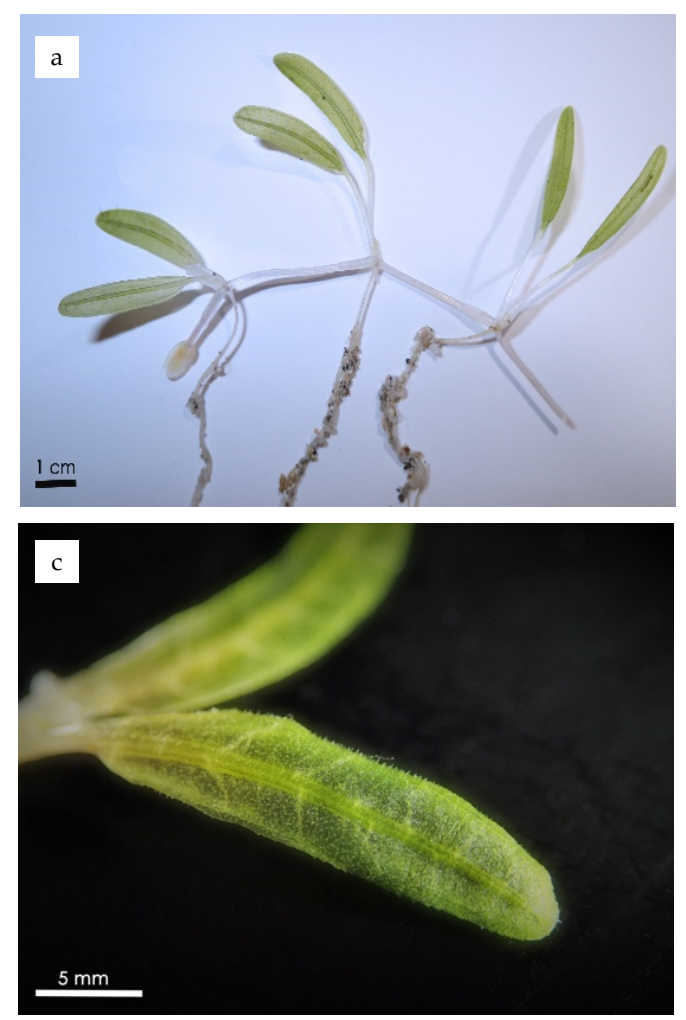
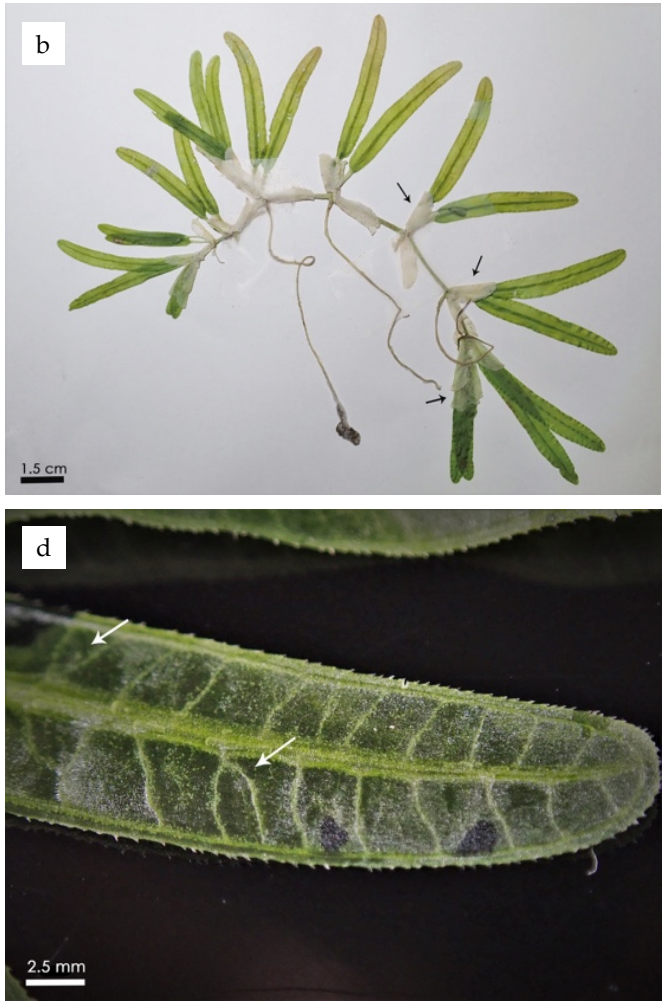

Figure 1. Cont. 

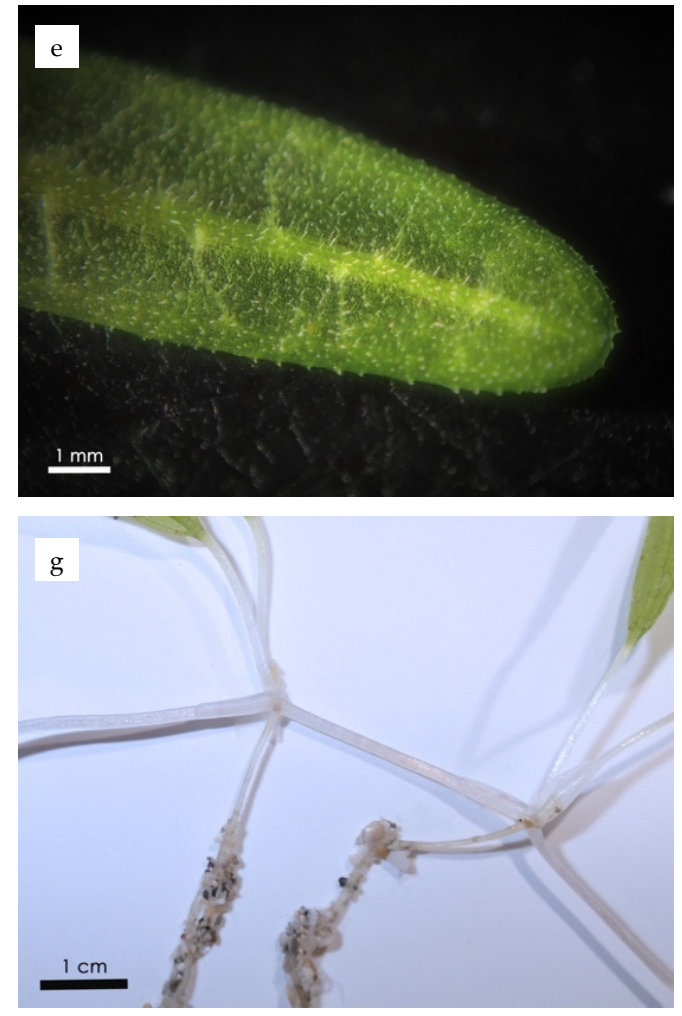
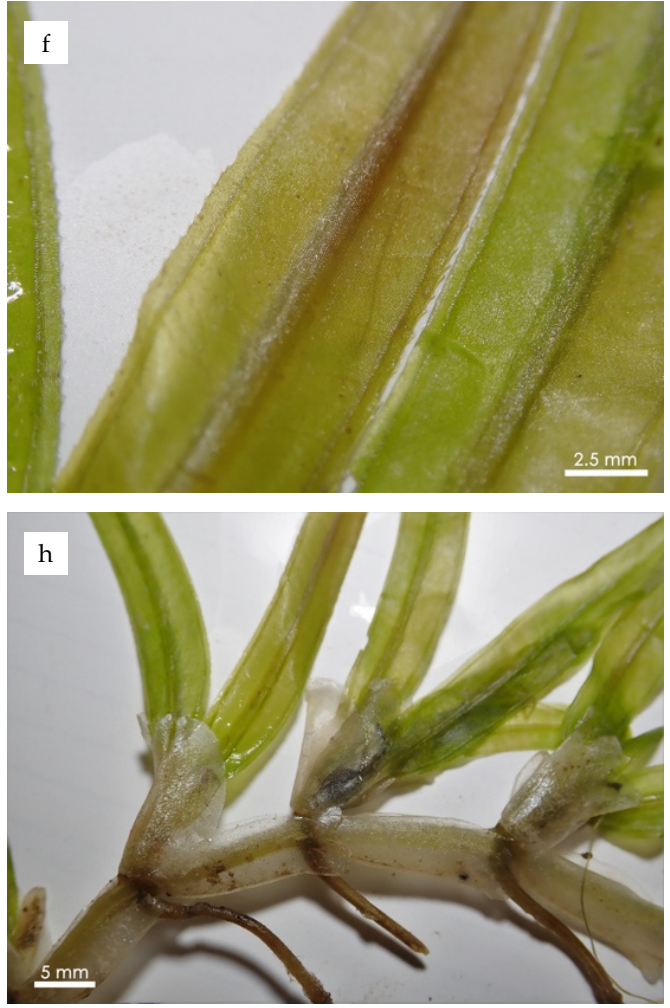

Figure 1. (a) A portion of Halophila sp. plant with leaf blades, apical meristem, rhizome, and roots. Scale bar $=1 \mathrm{~cm}$. (b) A portion of $H$. stipulacea plant with linear to oblong leaf blades, scales (black arrows), rhizome, and roots. Scale bar $=1.5 \mathrm{~cm}$. (c) Halophila sp. leaf blade with unbranched crossveins, intra-marginal veins, and midrib. Scale bar $=5 \mathrm{~mm}$. (d) H. stipulacea leaf blade showing serrated margin, numerous branched cross-veins (white arrows), intra-marginal vein, and midrib. Scale bar $=2.5 \mathrm{~mm}$. (e) Close-up of Halophila sp. leaf blade showing serrate margin and a dense covering of minute unicellular hairs on the surface. Scale bar $=1 \mathrm{~mm}$. (f) Close-up of H. stipulacea leaf blade with lack of minute hair and finely serrated margins. Scale bar $=2.5 \mathrm{~mm}$. (g) Halophila sp. without persistent scales. Scale bar $=1 \mathrm{~cm}$. (h) H. stipulacea showing large, persistent, transparent scales sheathing the petioles of leaf pairs. Scale bar $=5 \mathrm{~mm}$. The photos from the left column are originally from Gerakaris et al. (2020) [39].

\subsection{Genetic Identification}

DNA isolation and sequencing were successful for all three barcodes in all samples. After quality correction, a final sequence of $521 \mathrm{bp}$ for rbcL, $814 \mathrm{bp}$ for matK, and $646 \mathrm{bp}$ for ITS was obtained. The sequences for all three barcodes were uploaded to GenBank under the accession numbers OM160754-OM160761 for rbcL, OM160762-OM160769 for matK, and OM162162-OM162169 for ITS. There were no nucleotide differences between replicates for each site; therefore, only one sequence per site was used for downstream analyses. No nucleotide differences were found between specimens morphologically identified as $H$. decipiens (Halophila sp.) from Salamina Island and H. stipulacea from Crete for any of the barcodes, suggesting that all samples belong to the same species. The ITS region was used for the phylogenetic analysis because it has the highest resolution $[56,78]$ and the largest number of sequences available on GenBank NCBI, both in terms of the number of Halophila species and the number of samples within species. For the other two DNA barcodes, there are currently only a very small number of Halophila reference sequences available, not representative of the inter and intraspecific variability of the Halophila genus, required to build a well-founded phylogenetic tree and establish limits between species. Therefore, we based our genetic identification analysis mainly on the ITS region. A final alignment of $621 \mathrm{bp}$ (including gaps) was made for the 44 Halophila ITS sequences, of 
which $418(67.31 \%)$ were conserved sites, $196(31.56 \%)$ were variable sites, $145(23.35 \%)$ were parsimony-informative sites, and $51(8.21 \%)$ were singletons. Between $H$. decipiens (9 sequences) and $H$. stipulacea ( 7 sequences), 563 sites (90.66\%) were conserved, 41 sites $(6.6 \%)$ were variable, 36 sites $(5.8 \%)$ were parsimony-informative, and 5 sites $(0.81 \%)$ were singletons. There was no overlap between the greatest intraspecific distance (0.01) and the smallest interspecific distance (0.06), also known as the barcoding gap. As for the phylogenetic analysis, there were no meaningful topological differences between the ML and NJ inference trees. The tree obtained by the ML method is shown in Figure 2. The sequences of $H$. decipiens and $H$. stipulacea formed two clearly distinct monophyletic clades, regardless of the geographical origin of the samples. The specimens morphologically identified as $H$. decipiens (Halophila sp.) based on the recent taxonomic key clustered with $H$. stipulacea in a monophyletic clade, hence, the genetic result does not support the vegetative morphologic species identification and suggests that the Halophila population found in Salamina Island corresponds to a morphological variant of $H$. stipulacea.

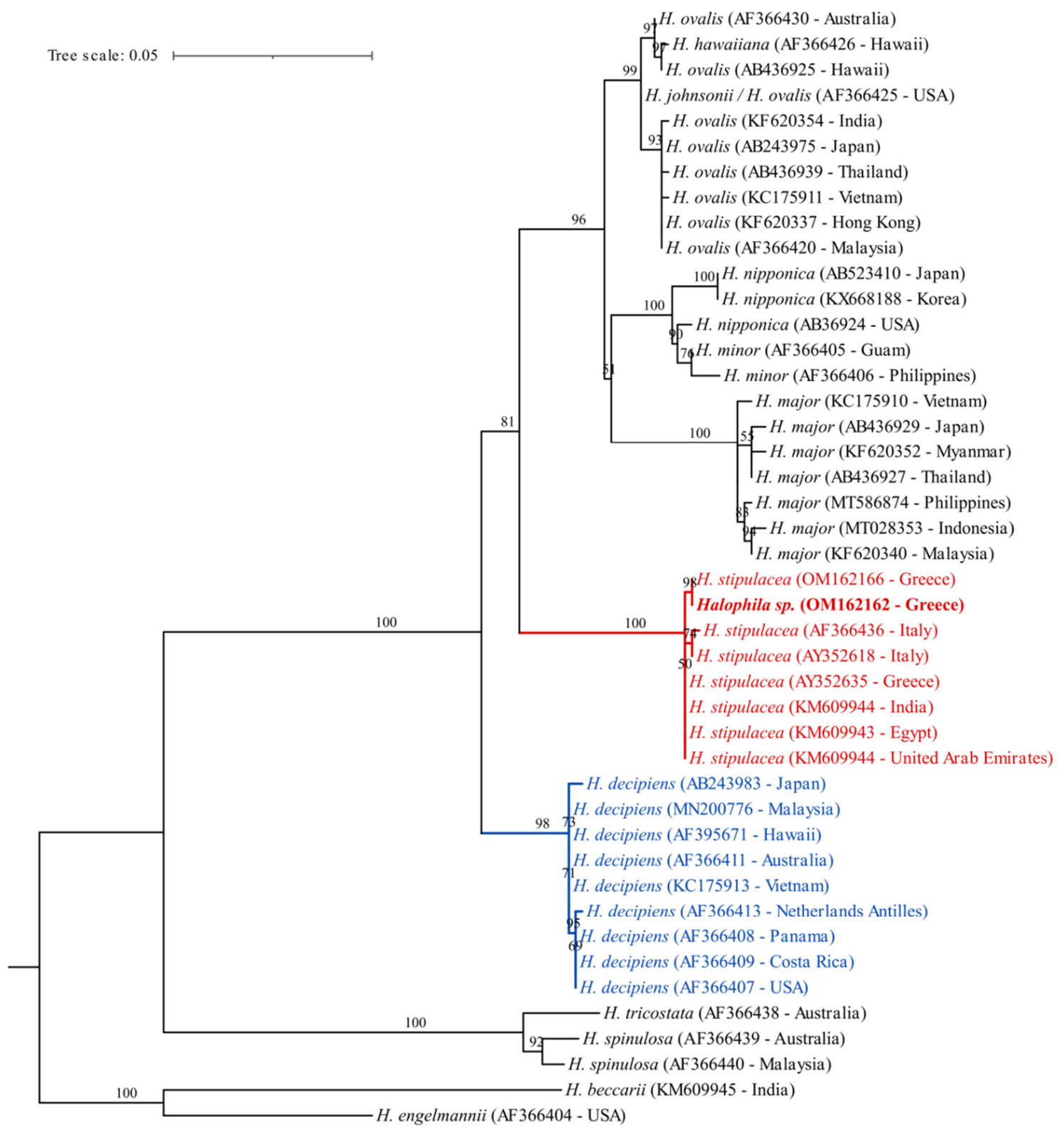

Figure 2. Phylogeny of the Halophila genus inferred from ML analysis based on 44 sequences of $621 \mathrm{bp}$ (including gaps) of the ITS region. The bootstrap values of ML are shown in each node; values < 50 were 
excluded. The species in bold corresponds to the specimen morphologically identified as $H$. decipiens found off Salamis, Greece. For sequence AF366425 we included the names H. johnsonii and H. ovalis, since recently a genomic-based phylogenetic and population analysis concluded that given the lack of genetic diversity, the ongoing recognition of $H$. johnsonii is unsupported and $H$. johnsonii and should be considered morphological variants of the same species [79]. Furthermore, the H. hawaiiana is currently considered an ecotype of $H$. ovalis; therefore, its taxonomic status should be taken with caution until a phylogenomic study takes place.

\section{Discussion}

The Halophila specimens from Salamina Island, morphologically described as H. decipiens (Halophila sp.) [39], did not show any nucleotide differences in the three DNA barcodes (ITS, rbcL, and matK) when compared to the H. stipulacea specimens from Crete, a population established in the Mediterranean Sea many years ago, suggesting that the specimens belong to the same species. This was further confirmed by the ITS maximum-likelihood and neighbor-joining phylogenetic trees, in which the Halophila sp. from Salamina Island formed a monophyletic clade together with $H$. stipulacea. The discriminatory power of the ITS region is not equal across the whole genus and is not able to resolve all morphologic and genetic conflicts, especially for the so-called H. ovalis complex (H. ovalis, H. hawaiiana, and $H$. johnsonii). However, in the case of H. stipulacea and H. decipiens the ITS region has a high species discriminatory power based on: (i) the two clearly distinct monophyletic clades containing a diverse representation of samples from widespread geographic origins; and (ii) the lack of overlap between the ITS greatest intraspecific distance (0.01) and the smallest interspecific distance (0.06), also called the barcoding gap, which is a condition necessary for the use of DNA barcoding in species identification. Apart from this study, ITS has also helped distinguish between H. major and H. ovalis in Japan [57] and Vietnam [65], confirmed that $H$. nipponica from Japan and Korea are the same species [64], identified the $H$. ovalis subsp. bullosa as conspecific with $H$. ovalis [80], confirmed the first record of $H$. major in Sri Lanka previously misidentified as $\mathrm{H}$. ovalis, and helped find the first hybridization case of Halophila crossed between H. ovalis and H. major [78]. Above all, ITS has already been used in $H$. decipiens identification, by confirming the first report of this species in Kenya where it can easily be misidentified as H. ovalis [81]. The increase in successful studies based on the ITS region supports the idea that this marker can be an effective tool for species identification or confirmation of taxa where taxonomic ambiguity exists due to similar morphological characters and phenotypic plasticity [82], as is often the case in the widespread seagrass genus Halophila. However, the inclusion of the missing Halophila species, increasing the geographic cover, and resolving the Halophila ovalis complex and other unresolved species delimitations are still required to test the universality of this marker for the entire genus. If barcoding alone is insufficient, a comparative phylogenomic approach may be required to solve some of the current taxonomic ambiguities [79]. In addition, a revision of the current ITS barcoding database is needed to correct possible previous misidentifications and track changes in species delimitations, as these may lead to misinterpretations in future molecular analysis. As for the other two DNA barcodes included in the analysis, the rbcL and matK plastid genes have been widely used in plants and are currently recommended as the plant DNA barcode system by the CBOL [58]. However, the universality and effectiveness of these plastid regions varies among plant groups. The discriminatory power of a DNA barcode can be affected, among other things, by the inter and intraspecific divergence (barcoding gap) and the extent of the barcode library $[83,84]$. In the case of Halophila, these genes are highly under-sampled, so the current barcode library does not allow an appropriate characterization of the genetic variability. Moreover, based on the few rbcL and matK studies, these plastid markers have shown a low interspecific genetic variability among seagrasses, especially for the complex Halophila genus, limiting its resolution at the family and genus levels [56,61]. For these reasons, these regions were not considered for the species genetic identification here and the ITS region alone was used instead. Nevertheless, the sequences generated for the rbcL and matK 
plastid barcodes and the lack of nucleotide differences among the specimens are important contributions to the seagrass DNA barcoding database for future phylogenetic studies.

In terms of morphological identification, the new taxonomic key of Kuo (2020) [62] has only minor and non-decisive changes in the diagnostic characters of the species. Therefore, the morphological characters of the specimens of Halophila sp. collected from Salamina Island still match well with those of $H$. decipiens, especially the low number and type of cross-veins and the structure of the scales. Finding molecular and morphological discordances in species identification is not uncommon. Since the advent of molecular analyses, revision of taxonomic classifications based solely on morphology has led to numerous changes in species delimitations and correction of previously overlooked misidentifications. Discordances may be the result of hybridization, introgression, cryptic species, early speciation, or high phenotypic plasticity leading to morphological variability [85-90]. In the absence of previous records of $\mathrm{H}$. decipiens in the Mediterranean Sea, crossing with $\mathrm{H}$. stipulacea resulting in a hybrid is unlikely, and the high ITS region similarity also suggests this (Figure 2). On the other hand, environmentally induced phenotypic plasticity is a common response mechanism in seagrasses, including in growth, reproduction, and morphological variability $[44,91,92]$. High phenotypic plasticity is also a common feature of invasive species, which allows them to survive under changing environmental conditions [93,94]. Therefore, finding morphological differences among $H$. stipulacea populations throughout the basin is not surprising and may explain the current discordance between morphological and molecular analyses. Considering both taxonomic characterizations (morphological and molecular), the genetic result is strongly supported by the high discriminatory power of the ITS region. On the contrary, the known morphologic variability of the genus and the lack of reproductive features during identification makes the morphologic identification more susceptible to misidentifications. Therefore, based on the unequivocal genetic result, the specimens found in Salamina Island, despite their morphologic similarity to H. decipiens, correspond to a morphological variant of $H$. stipulacea.

The specific characteristics of the new morphological variant of $H$. stipulacea (i.e., its leaf length and width, number and type of cross-veins, size, type, and structure of scales) are of great taxonomic value, and their inclusion in future taxonomic keys is strongly recommended. However, the morphologic variability of $H$. stipulacea, which has led to its misidentification as $H$. decipiens, highlights the limitations of identifying species with overlapping and highly variable morphological characters using traditional morphological identification alone. This is even more true in the absence of reproductive structures, the main distinct sources for the species identification of flowering plants. In the case of these two species, $H$. decipiens is monoecious (male and female flowers on the same spathe) and H. stipulacea is dioecious (male and female flowers on different individual plants) [62]. Therefore, the use of an integrative taxonomy that includes morphological and DNA-based analyses is recommended to avoid future misidentifications and to help resolve current taxonomic discrepancies, which is needed to understand past and future range shifts in this highly complex, diverse, and widespread genus.

Further development and integration of DNA-based analyses into seagrass studies will not only aid species delimitation and reduce misidentification but will also allow the application of techniques such as metabarcoding and environmental DNA (eDNA) to monitoring shifts in native seagrasses ranges. Rapid and accurate identification of species is important for monitoring NIS, as it can impact efforts to mitigate the threats posed by them [46]. For seagrasses known to disperse by commercial vessels, molecular analysis of ballast water can be of great benefit to detecting potential sources of invasion [47], as can the inclusion of seagrasses in eDNA surveys of water and sediment near marinas or ports, which are common invasive habitats. A universal macrophyte minibarcode (18S DNA) has recently been developed; however, its current low species-level resolution [95] limits its use in monitoring species range shifts. Therefore, for monitoring Halophila and other seagrasses, ITS target species analysis remains a better option. Active monitoring is even more important now that $H$. stipulacea has reached the French Riviera 30 years earlier than 
what habitat suitability models predicted, considering future changes in temperature and salinity under climate change [34]. This is an indication that we may be underestimating the ability of this species to invade new habitats and that its spread may be faster than originally thought $[28,96]$. A concerted effort is needed to expand the in-depth morphological, molecular, and ecological descriptions of $H$. stipulacea populations throughout the basin. This will help to establish a more representative taxonomic database for the identification of the species, as well as provide essential information on the plasticity and/or adaptability of the species, contributing to an understanding of the complex evolutionary and ecological mechanisms that govern its invasion dynamics. Furthermore, although it should be considered a positive outcome that $H$. decipiens has not yet entered the Mediterranean Sea, suitable environmental conditions already exist in the Levantine Sea and are expected to expand to other areas of the basin in the coming years [34], so its introduction can be expected in the future and active monitoring is required.

\section{Conclusions}

Considering the high species discriminatory power of the ITS DNA barcode, and the common morphological variabilities and taxonomic ambiguities within the genus, known to lead to misidentifications. We conclude that the unequivocal genetic result does not support the vegetative morphologic identification and suggests that the Halophila population found in Salamina Island can be considered a morphological variant of $H$. stipulacea. This means that $H$. stipulacea remains the only non-indigenous seagrass species in the Mediterranean Sea. Our results highlight the importance of integrating morphological and molecular analyses of taxonomically complex and widespread genera such as Halophila, to avoid overlooking or misreporting species range shifts, which are essential for monitoring and managing NIS introductions.

Author Contributions: Conceptualization, E.T.A.; field work, V.G.; methodology, A.T.; molecular analysis, C.A.G.-E. and A.T.; taxonomic analysis, V.G.; writing-original draft preparation, C.A.G.-E.; writing-review and editing, E.T.A., V.G. and C.S.T.; supervision, E.T.A.; project administration, E.T.A.; funding acquisition, E.T.A. All authors have read and agreed to the published version of the manuscript.

Funding: This research was co-financed by Greece and the European Union (European Social FundESF) through the Operational Programme 'Human Resources Development, Education and Lifelong Learning 2014-2020' in the context of the project 'I-ADAPT' (MIS 5006611).

Data Availability Statement: The sequences generated on this study are available on GenBank, NCBI (https:/ / www.ncbi.nlm.nih.gov/) under the accession numbers OM160754-OM160761 for rbcL, OM160762-OM160769 for matK, and OM162162-OM162169 for ITS.

Acknowledgments: We thank Vaso Terzoglou for assistance in laboratory work, Thanos Dailianis for helping in the field, and the reviewers for their comments and constructive criticism that helped us improve the paper.

Conflicts of Interest: The authors declare no conflict of interest.

\section{References}

1. Hulme, P.E. Trade, Transport and Trouble: Managing Invasive Species Pathways in an Era of Globalization. J. Appl. Ecol. 2009, 46, 10-18. [CrossRef]

2. Seebens, H.; Blackburn, T.M.; Dyer, E.E.; Genovesi, P.; Hulme, P.E.; Jeschke, J.M.; Pagad, S.; Pyšek, P.; Winter, M.; Arianoutsou, M.; et al. No Saturation in the Accumulation of Alien Species Worldwide. Nat. Commun. 2017, 8, 14435. [CrossRef]

3. Pecl, G.; Araujo, M.B.; Bell, J.D.; Blanchard, J.; Bonebrake, T.C.; Pecl, G.T.; Araujo, M.B.; Bell, J. Biodiversity Redistribution under Climate Change: Impacts on Ecosystems and Human Well-Being Publication Details. Science 2017, 355, 1-9. [CrossRef]

4. Gallardo, B.; Clavero, M.; Sánchez, M.I.; Vilà, M. Global Ecological Impacts of Invasive Species in Aquatic Ecosystems. Glob. Chang. Biol. 2016, 22, 151-163. [CrossRef]

5. Worm, B.; Barbier, E.B.; Beaumont, N.; Duffy, E.; Folke, C.; Halpern, B.S.; Jackson, J.B.C.; Lotze, H.K.; Micheli, F.; Palumbi, S.R.; et al. Impacts of Biodiversity Loss on Ocean Ecosystem Services. Science 2006, 314, 787-790. [CrossRef] 
6. Costello, M.J.; Coll, M.; Danovaro, R.; Halpin, P.; Ojaveer, H.; Miloslavich, P. A Census of Marine Biodiversity Knowledge, Resources, and Future Challenges. PLoS ONE 2010, 5, e12110. [CrossRef]

7. Edelist, D.; Rilov, G.; Golani, D.; Carlton, J.T.; Spanier, E. Restructuring the Sea: Profound Shifts in the World's Most Invaded Marine Ecosystem. Divers. Distrib. 2013, 19, 69-77. [CrossRef]

8. Zenetos, A.; Galanidi, M. Mediterranean Non Indigenous Species at the Start of the 2020s: Recent Changes. Mar. Biodivers. Rec. 2020, 13, 10. [CrossRef]

9. Orfanidis, S.; Alvito, A.; Azzurro, E.; Badreddine, A.; Souissi, J.B.; Chamorro, M.; Crocetta, F.; Dalyan, C.; FortiČ, A.; Galanti, L.; et al. New Alien Mediterranean Biodiversity Records (March 2021). Mediterr. Mar. Sci. 2021, 22, 180-198. [CrossRef]

10. Lodge, D.M. Biological Invasions: Lessons for Ecology. Trends Ecol. Evol. 1993, 8, 133-137. [CrossRef]

11. Galil, B.S. A Sea under Siege-Alien Species in the Mediterranean. Biol. Invasions 2000, 2, 177-186. [CrossRef]

12. Zenetos, A.; Gofas, S.; Morri, C.; Rosso, A.; Violanti, D.; García Raso, J.E.; Çinar, M.E.; Almogi-Labin, A.; Ates, A.S.; Azzurro, E.; et al. Alien Species in the Mediterranean Sea by 2012. A Contribution to the Application of European Union's Marine Strategy Framework Directive (MSFD). Part 2. Introduction Trends and Pathways. Mediterr. Mar. Sci. 2012, 13, 328-352. [CrossRef]

13. Molnar, J.L.; Gamboa, R.L.; Revenga, C.; Spalding, M.D. Assessing the Global Threat of Invasive Species to Marine Biodiversity. Front. Ecol. Environ. 2008, 6, 485-492. [CrossRef]

14. Bianchi, C.N.; Morri, C. Global Sea Warming and "Tropicalization" of the Mediterranean Sea: Biogeographic and Ecological Aspects. Biogeogr.-J. Integr. Biogeogr. 2003, 24. [CrossRef]

15. Coll, M.; Piroddi, C.; Steenbeek, J.; Kaschner, K.; Lasram, F.B.R.; Aguzzi, J.; Ballesteros, E.; Bianchi, C.N.; Corbera, J.; Dailianis, T.; et al. The Biodiversity of the Mediterranean Sea: Estimates, Patterns, and Threats. PLoS ONE 2010, 5 , e11842. [CrossRef] [PubMed]

16. Reverdin, G.; Bosse, A.; Juza, M.; Tintoré, J. Multivariate Sub-Regional Ocean Indicators in the Mediterranean Sea: From Event Detection to Climate Change Estimations. Front. Mar. Sci. 2021, 8, 233. [CrossRef]

17. Raitsos, D.E.; Beaugrand, G.; Georgopoulos, D.; Zenetos, A.; Pancucci-Papadopoulou, A.M.; Theocharis, A.; Papathanassiou, E. Global Climate Change Amplifies the Entry of Tropical Species into the Eastern Mediterranean Sea. Limnol. Oceanogr. 2010, 55, 1478-1484. [CrossRef]

18. Albano, P.G.; Steger, J.; Bošnjak, M.; Dunne, B.; Guifarro, Z.; Turapova, E.; Hua, Q.; Kaufman, D.S.; Rilov, G.; Zuschin, M. Native Biodiversity Collapse in the Eastern Mediterranean. Proc. R. Soc. B Biol. Sci. 2021, 288, 20202469. [CrossRef]

19. Hoffman, R. Alien Benthic Algae and Seagrasses in the Mediterranean Sea and Their Connection to Global Warming. In The Mediterranean Sea; Springer: Dordrecht, The Netherlands, 2014; pp. 159-181. [CrossRef]

20. Cullen-Unsworth, L.C.; Nordlund, L.M.; Paddock, J.; Baker, S.; McKenzie, L.J.; Unsworth, R.K.F. Seagrass Meadows Globally as a Coupled Social-Ecological System: Implications for Human Wellbeing. Mar. Pollut. Bull. 2014, 83, 387-397. [CrossRef] [PubMed]

21. Nordlund, L.M.; Koch, E.W.; Barbier, E.B.; Creed, J.C. Seagrass Ecosystem Services and Their Variability across Genera and Geographical Regions. PLoS ONE 2016, 11, e0163091. [CrossRef] [PubMed]

22. den Hartog, C. Range Extension of Halophila stipulacea (Hydrocharitaceae) in the Mediterranean. Blumea 1972, 20, 154-156.

23. Lipkin, Y. Halophila stipulacea, a Review of a Successful Immigration. Aquat. Bot. 1975, 1, 203-215. [CrossRef]

24. Lipkin, Y. Halophila stipulacea in Cyprus and Rhodes, 1967-1970. Auqat. Bot. 1975, 1, 309-320. [CrossRef]

25. den Hartog, C. The Sea-Grasses of the World; North-Holland Publishing Company: Amsterdam, The Netherlands, 1970; Volume 59.

26. Fritsch, C. Ueber Die Auffindung Einer Marinen Hydrocharideeim Mittelmeer. Verh. Zool. Bot. Ges. 1895, 45, $104-106$.

27. Winters, G.; Beer, S.; Willette, D.A.; Viana, I.G.; Chiquillo, K.L.; Beca-Carretero, P.; Villamayor, B.; Azcárate-García, T.; Shem-Tov, R.; Mwabvu, B.; et al. The Tropical Seagrass Halophila stipulacea: Reviewing What We Know from Its Native and Invasive Habitats, alongside Identifying Knowledge Gaps. Front. Mar. Sci. 2020, 7, 1-28. [CrossRef]

28. Gambi, M.C.; Barbieri, F.; Bianchi, C.N. New Record of the Alien Seagrass Halophila stipulacea (Hydrocharitaceae) in the Western Mediterranean: A Further Clue to Changing Mediterranean Sea Biogeography. Mar. Biodivers. Rec. 2009, 2, 1-7. [CrossRef]

29. Biliotti, M.; Abdelahad, N. Halophila stipulacea (Forssk.) Aschers.(Hydrocharitaceae): Espèce Nouvelle Pour l'Italie. Posidonia Newsl. 1990, 3, 23-26.

30. Missaoui, H.; Mahjoub, S.; Chalghaf, M. Sur La Présence de La Phanérogame Marine Halophila stipulacea (Forsskål) Dans Le Golfe de Gabes. Bull. Inst. Nat. Sci. Technol. Mer Salammbô 2003, 30, 111-114.

31. Sghaier, Y.R.; Zakhama-Sraieb, R.; Benamer, I.; Charfi-Cheikhrouha, F. Occurrence of the Seagrass Halophila stipulacea (Hydrocharitaceae) in the Southern Mediterranean Sea. Bot. Mar. 2011, 54, 575-582. [CrossRef]

32. Thibaut, T.; Blanfuné, A.; Boudouresque, C.F.; Holon, F.; Agel, N.; Descamps, P.; Deter, J.; Pavy, T.; Delaruelle, G.; Verlaque, M. Distribution of the Seagrass Halophila stipulacea: A Big Jump to the Northwestern Mediterranean Sea. Aquat. Bot. 2022, $176,103465$. [CrossRef]

33. Willette, D.A.; Chalifour, J.; Debrot, A.O.D.; Engel, M.S.; Miller, J.; Oxenford, H.A.; Short, F.T.; Steiner, S.C.C.; Védie, F. Continued Expansion of the Trans-Atlantic Invasive Marine Angiosperm Halophila stipulacea in the Eastern Caribbean. Aquat. Bot. 2014, 112, 98-102. [CrossRef]

34. Beca-Carretero, P.; Teichberg, M.; Winters, G.; Procaccini, G.; Reuter, H. Projected Rapid Habitat Expansion of Tropical Seagrass Species in the Mediterranean Sea as Climate Change Progresses. Front. Plant Sci. 2020, 11, 555376. [CrossRef] 
35. Telesca, L.; Belluscio, A.; Criscoli, A.; Ardizzone, G.; Apostolaki, E.T.; Fraschetti, S.; Gristina, M.; Knittweis, L.; Martin, C.S.; Pergent, G.; et al. Seagrass Meadows (Posidonia oceanica) Distribution and Trajectories of Change. Sci. Rep. 2015, 5, 12505. [CrossRef]

36. Boudouresque, C.F.; Bernard, G.; Pergent, G.; Shili, A.; Verlaque, M. Regression of Mediterranean Seagrasses Caused by Natural Processes and Anthropogenic Disturbances and Stress: A Critical Review. Bot. Mar. 2009, 52, 395-418. [CrossRef]

37. Montefalcone, M.; Morri, C.; Peirano, A.; Albertelli, G.; Bianchi, C.N. Substitution and Phase Shift within the Posidonia oceanica Seagrass Meadows of NW Mediterranean Sea. Estuar. Coast. Shelf Sci. 2007, 75, 63-71. [CrossRef]

38. Montefalcone, M.; Albertelli, G.; Morri, C.; Bianchi, C.N. Patterns of Wide-Scale Substitution within Meadows of the Seagrass Posidonia oceanica in NW Mediterranean Sea: Invaders Are Stronger than Natives. Aquat. Conserv. Mar. Freshw. Ecosyst. 2010, 20,507-515. [CrossRef]

39. Gerakaris, V.; Lardi, P.L.; Issaris, Y. First Record of the Tropical Seagrass Species Halophila decipiens Ostenfeld in the Mediterranean Sea. Aquat. Bot. 2020, 160, 103151. [CrossRef]

40. Short, F.; Carruthers, T.; Dennison, W.; Waycott, M. Global Seagrass Distribution and Diversity: A Bioregional Model. J. Exp. Mar. Biol. Ecol. 2007, 350, 3-20. [CrossRef]

41. Green, E.P.; Short, F.T.; Frederick, T. World Atlas of Seagrasses; University of California Press: Berkeley, CA, USA, 2003.

42. Gorman, D.; Turra, A.; Bergstrom, E.R.; Horta, P.A. Population Expansion of a Tropical Seagrass (Halophila decipiens) in the Southwest Atlantic (Brazil). Aquat. Bot. 2016, 132, 30-36. [CrossRef]

43. Schubert, N.; Demes, K. Phenotypic Plasticity in the Marine Angiosperm Halophila decipiens (Hydrocharitaceae, Streptophyta). Mar. Ecol. Prog. Ser. 2017, 575, 81-93. [CrossRef]

44. Rozaimi, M.; Arina, N.; Zainee, N.F.A.; Raynusha, C.; Hidayah, N. An Uncommon Intertidal Record of Halophila decipiens Ostenfeld in the Vicinity of Mangroves. Aquat. Bot. 2020, 160, 103168. [CrossRef]

45. Thresher, R.E.; Kuris, A.M. Options for Managing Invasive Marine Species. Biol. Invasions 2004, 6, 295-300. [CrossRef]

46. Mehta, S.V.; Haight, R.G.; Homans, F.R.; Polasky, S.; Venette, R.C. Optimal Detection and Control Strategies for Invasive Species Management. Ecol. Econ. 2007, 61, 237-245. [CrossRef]

47. Westfall, K.M.; Therriault, T.W.; Abbott, C.L. A New Approach to Molecular Biosurveillance of Invasive Species Using DNA Metabarcoding. Glob. Chang. Biol. 2020, 26, 1012-1022. [CrossRef] [PubMed]

48. Darling, J.A.; Blum, M.J. DNA-Based Methods for Monitoring Invasive Species: A Review and Prospectus. Biol. Invasions 2007, 9, 751-765. [CrossRef]

49. Dayrat, B. Towards Integrative Taxonomy. Biol. J. Linn. Soc. 2005, 85, 407-417. [CrossRef]

50. Hebert, P.D.N.; Cywinska, A.; Ball, S.L.; DeWaard, J.R. Biological Identifications through DNA Barcodes. Proc. R. Soc. B Biol. Sci. 2003, 270, 313-321. [CrossRef]

51. Andújar, C.; Arribas, P.; Yu, D.W.; Vogler, A.P.; Emerson, B.C. Why the COI Barcode Should Be the Community DNA Metabarcode for the Metazoa. Mol. Ecol. 2018, 27, 3968-3975. [CrossRef]

52. Kress, W.J.; Wurdack, K.J.; Zimmer, E.A.; Weigt, L.A.; Janzen, D.H. Use of DNA Barcodes to Identify Flowering Plants. Proc. Natl. Acad. Sci. USA 2005, 102, 8369-8374. [CrossRef]

53. Li, X.; Yang, Y.; Henry, R.J.; Rossetto, M.; Wang, Y.; Chen, S. Plant DNA Barcoding: From Gene to Genome. Biol. Rev. Camb. Philos. Soc. 2015, 90, 157-166. [CrossRef]

54. Chase, M.W.; Salamin, N.; Wilkinson, M.; Dunwell, J.M.; Kesanakurthi, R.P.; Haidar, N.; Savolainen, V. Land Plants and DNA Barcodes: Short-Term and Long-Term Goals. Philos. Trans. R. Soc. B Biol. Sci. 2005, 360, 1889. [CrossRef]

55. Trivedi, S.; Aloufi, A.A.; Ansari, A.A.; Ghosh, S.K. Role of DNA Barcoding in Marine Biodiversity Assessment and Conservation: An Update. Saudi J. Biol. Sci. 2016, 23, 161-171. [CrossRef] [PubMed]

56. Nguyen, X.-V.; Höfler, S.; Glasenapp, Y.; Thangaradjou, T.; Lucas, C.; Papenbrock, J. New insights into DNA barcoding of seagrasses. Syst. Biodivers. 2015, 13, 496-508. [CrossRef]

57. Uchimura, M.; Jean Faye, E.; Shimada, S.; Inoue, T.; Nakamura, Y. A Reassessment of Halophila Species (Hydrocharitaceae) Diversity with Special Reference to Japanese Representatives. Bot. Mar. 2008, 51, 258-268. [CrossRef]

58. Hollingsworth, P.M.; Forrest, L.L.; Spouge, J.L.; Hajibabaei, M.; Ratnasingham, S.; van der Bank, M.; Chase, M.W.; Cowan, R.S.; Erickson, D.L.; Fazekas, A.J.; et al. A DNA Barcode for Land Plants. Proc. Natl. Acad. Sci. USA 2009, 106, 12794-12797. [CrossRef]

59. Li, D.Z.; Gao, L.M.; Li, H.T.; Wang, H.; Ge, X.J.; Liu, J.Q.; Chen, Z.D.; Zhou, S.L.; Chen, S.L.; Yang, J.B.; et al. Comparative Analysis of a Large Dataset Indicates That Internal Transcribed Spacer (ITS) Should Be Incorporated into the Core Barcode for Seed Plants. Proc. Natl. Acad. Sci. USA 2011, 108, 19641-19646. [CrossRef]

60. Waycott, M.; Freshwater, W.D.; York, R.A.; Calladine, A.; Kenworthy, J.W. Evolutionary Trends in the Seagrass Genus Halophila (Thouars): Insights from Molecular Phylogeny. Bull. Mar. Sci. 2002, 71, 1299-1308.

61. Lucas, C.; Thangaradjou, T.; Papenbrock, J. Development of a DNA Barcoding System for Seagrasses: Successful but Not Simple. PLoS ONE 2012, 7, e29987. [CrossRef]

62. Kuo, J. Taxonomy of the Genus Halophila Thouars (Hydocharitaceae): A Review. Plants 2020, 9, 1732. [CrossRef] [PubMed]

63. Kuo, J.; den Hartog, C. "Seagrass Taxonomy and Identification Key" Global Seagrass Research Methods. In Global Seagrass Research Methods; Short, F.T., Coler, R.G., Eds.; Elsevier Science B.V: Amsterdam, The Netherlands, 2001; pp. 31-58.

64. Kim, Y.K.; Kim, S.H.; Yi, J.M.; Kang, C.K.; Short, F.; Lee, K.S. Genetic Identification and Evolutionary Trends of the Seagrass Halophila nipponica in Temperate Coastal Waters of Korea. PLoS ONE 2017, 12, e0177772. [CrossRef] [PubMed] 
65. Nguyen, X.-V.; Holzmeyer, L.; Papenbrock, J. New Record of the Seagrass Species Halophila Major (Zoll.) Miquel in Vietnam: Evidence from Leaf Morphology and ITS Analysis. Bot. Mar. 2013, 56, 313-321. [CrossRef]

66. Phillips, R.C.; Mehez, E.G. Seagrasses, 34th ed.; Smithsonian Institution Scholarly Press: Washington, DC, USA, 1988.

67. Thompson, J.D.; Higgins, D.G.; Gibson, T.J. CLUSTAL W: Improving the Sensitivity of Progressive Multiple Sequence Alignment through Sequence Weighting, Position-Specific Gap Penalties and Weight Matrix Choice. Nucleic Acids Res. 1994, 22, 4673-4680. [CrossRef]

68. Kumar, S.; Stecher, G.; Tamura, K. MEGA7: Molecular Evolutionary Genetics Analysis Version 7.0 for Bigger Datasets. Mol. Biol. Evol. 2016, 33, 1870-1874. [CrossRef]

69. Darriba, D.; Taboada, G.L.; Doallo, R.; Posada, D. JModelTest 2: More Models, New Heuristics and Parallel Computing. Nat. Methods 2012, 9, 772. [CrossRef]

70. Trifinopoulos, J.; Nguyen, L.T.; von Haeseler, A.; Minh, B.Q. W-IQ-TREE: A Fast Online Phylogenetic Tool for Maximum Likelihood Analysis. Nucleic Acids Res. 2016, 44, W232-W235. [CrossRef]

71. Minh, B.Q.; Schmidt, H.A.; Chernomor, O.; Schrempf, D.; Woodhams, M.D.; von Haeseler, A.; Lanfear, R.; Teeling, E. IQ-TREE 2 : New Models and Efficient Methods for Phylogenetic Inference in the Genomic Era. Mol. Biol. Evol. 2020, 37, 1530-1534. [CrossRef] [PubMed]

72. Nguyen, L.T.; Schmidt, H.A.; von Haeseler, A.; Minh, B.Q. IQ-TREE: A Fast and Effective Stochastic Algorithm for Estimating Maximum-Likelihood Phylogenies. Mol. Biol. Evol. 2015, 32, 268-274. [CrossRef]

73. Letunic, I.; Bork, P. Interactive Tree of Life (ITOL) v5: An Online Tool for Phylogenetic Tree Display and Annotation. Nucleic Acids Res. 2021, 49, W293-W296. [CrossRef] [PubMed]

74. Puillandre, N.; Lambert, A.; Brouillet, S.; Achaz, G. ABGD, Automatic Barcode Gap Discovery for Primary Species Delimitation. Mol. Ecol. 2012, 21, 1864-1877. [CrossRef] [PubMed]

75. Ruggiero, M.V.; Zoologica, S.; Dohrn, A.; Procaccini, G. The rDNA ITS Region in the Lessepsian Marine Angiosperm Halophila stipulacea (Forssk.) Aschers. (Hydrocharitaceae): Intragenomic Variability and Putat Climate Change Effects on Seagrass Secondary Metabolism: Ecological Implications View Project RITMARE View Project. Artic. J. Mol. Evol. 2004, 58, $115-121$. [CrossRef]

76. Nguyen, V.X.; Detcharoen, M.; Tuntiprapas, P.; Soe-Htun, U.; Sidik, J.B.; Harah, M.Z.; Prathep, A.; Papenbrock, J. Genetic Species Identification and Population Structure of Halophila (Hydrocharitaceae) from the Western Pacific to the Eastern Indian Ocean. BMC Evol. Biol. 2014, 14, 1-18. [CrossRef] [PubMed]

77. Kolátková, V.; Čepička, I.; Hoffman, R.; Vohník, M. Marinomyxa Gen. Nov. Accommodates Gall-Forming Parasites of the Tropical to Subtropical Seagrass Genus Halophila and Constitutes a Novel Deep-Branching Lineage Within Phytomyxea (Rhizaria: Endomyxa). Microb. Ecol. 2021, 81, 673-686. [CrossRef] [PubMed]

78. Liu, S.Y.V.; Kumara, T.P.; Hsu, C.H. Genetic Identification and Hybridization in the Seagrass Genus Halophila (Hydrocharitaceae) in Sri Lankan Waters. PeerJ 2020, 8, e10027. [CrossRef]

79. Waycott, M.; van Dijk, K.; Calladine, A.; Bricker, E.; Biffin, E. Genomics-Based Phylogenetic and Population Genetic Analysis of Global Samples Confirms Halophila johnsonii Eiseman as Halophila ovalis (R.Br.) Hook.f. Front. Mar. Sci. 2021, 8. [CrossRef]

80. Singh, S.; Southgate, P.C.; Lal, M.M. Morphological Plasticity in a Fijian Seagrass: Halophila ovalis Subsp. Bullosa. Reg. Stud. Mar Sci. 2019, 32, 100809. [CrossRef]

81. McMahon, K.M.; Waycott, M. New Record for Halophila decipiens Ostenfeld in Kenya Based on Morphological and Molecular Evidence. Aquat. Bot. 2009, 91, 318-320. [CrossRef]

82. Hubert, N.; Hanner, R. DNA Barcoding, Species Delineation and Taxonomy: A Historical Perspective. DNA Barcodes 2016, 3, 44-58. [CrossRef]

83. Hebert, P.D.N.; Stoeckle, M.Y.; Zemlak, T.S.; Francis, C.M. Identification of Birds through DNA Barcodes. PLoS Biol. 2004, 2, e312. [CrossRef]

84. Ekrem, T.; Willassen, E.; Stur, E. A Comprehensive DNA Sequence Library Is Essential for Identification with DNA Barcodes. Mol. Phylogenet. Evol. 2007, 43, 530-542. [CrossRef]

85. Demes, K.W.; Graham, M.H.; Suskiewicz, T.S. Phenotypic plasticity reconciles incongruous molecular and morphological taxonomies: The giant kelp, macrocystis (laminariales, phaeophyceae), is a monospecific genus 1. J. Phycol. 2009, 45, 1266-1269. [CrossRef]

86. Debiasse, M.B.; Hellberg, M.E. Discordance between Morphological and Molecular Species Boundaries among Caribbean Species of the Reef Sponge Callyspongia. Ecol. Evol. 2015, 5, 663-675. [CrossRef]

87. Goonesekera, K.; Lee, P.L.M.; van der Poorten, G.; Ranawaka, G. A Global Comparison of DNA Sequences of Pelopidas (Lepidoptera: Hesperiidae) Reveals Discordance between Morphological and Genetic Data, and an Insular 'Ghost' Population. Insect Conserv. Divers. 2021, 14, 81-94. [CrossRef]

88. Yurchenko, V.Y.; Lukeš, J.; Tesařová, M.; Jirků, M.; Maslov, D.A. Morphological Discordance of the New Trypanosomatid Species Phylogenetically Associated with the Genus Crithidia. Protist 2008, 159, 99-114. [CrossRef]

89. Trujillo-Arias, N.; Rodríguez-Cajarville, M.J.; Sari, E.; Miyaki, C.Y.; Santos, F.R.; Witt, C.C.; Barreira, A.S.; Gómez, I.; Naoki, K.; Tubaro, P.L.; et al. Evolution between Forest Macrorefugia Is Linked to Discordance between Genetic and Morphological Variation in Neotropical Passerines. Mol. Phylogenet. Evol. 2020, 149, 106849. [CrossRef] [PubMed] 
90. McManus, G.B.; Katz, L.A. Molecular and Morphological Methods for Identifying Plankton: What Makes a Successful Marriage? J. Plankton Res. 2009, 31, 1119-1129. [CrossRef]

91. McDonald, A.M.; Prado, P.; Heck, K.L.; Fourqurean, J.W.; Frankovich, T.A.; Dunton, K.H.; Cebrian, J. Seagrass Growth, Reproductive, and Morphological Plasticity across Environmental Gradients over a Large Spatial Scale. Aquat. Bot. 2016, 134, 87-96. [CrossRef]

92. Pazzaglia, J.; Reusch, T.B.H.; Terlizzi, A.; Marín-Guirao, L.; Procaccini, G. Phenotypic Plasticity under Rapid Global Changes: The Intrinsic Force for Future Seagrasses Survival. Evol. Appl. 2021, 14, 1181-1201. [CrossRef] [PubMed]

93. Pyšek, P.; Richardson, D.M. 7 Traits Associated with Invasiveness in Alien Plants: Where Do We Stand? Biol. Invasions 2008, 193, 97-125.

94. Daehler, C.C. Performance Comparisons of Co-Occurring Native and Alien Invasive Plants: Implications for Conservation and Restoration. Annu. Rev. Ecol. Evol. Syst. 2003, 34, 183-211. [CrossRef]

95. Ortega, A.; Geraldi, N.R.; Díaz-Rúa, R.; Oberg, S.B.; Wesselmann, M.; Kreuse-Jensen, D.; Duarte, C.M. A DNA Mini-barcode for marine macrophytes. Mol. Ecol. Resour. 2020, 20, 920-935. [CrossRef] [PubMed]

96. Nguyen, H.M.; Yadav, N.S.; Barak, S.; Lima, F.P.; Sapir, Y.; Winters, G. Responses of Invasive and Native Populations of the Seagrass Halophila stipulacea to Simulated Climate Change. Front. Mar. Sci. 2020, 6, 812. [CrossRef] 